\title{
Design of an Optimum Battery Electric Fishing Vessel for Natuna Sea
}

\author{
Juniarko Prananda ${ }^{1}$, Eddy Setyo Koenhardono ${ }^{2}$, Rivaldi Clarence Tjoa ${ }^{3}$ \\ (Received: 23 January 2018 / Revised: 10 July 2019 / Accepted: 26 September 2019)
}

\begin{abstract}
Natuna Sea is one of the places in Indonesia, which has a high potency of fish up to one million ton per year. Fisherman in Indonesia relies too much on the fossil fuel, which has limited resources. The author wants to redesign the fishing vessel into the battery electric fishing vessel that can be recharge to reduce the use of fossil fuel and also to increasing the revenue of the fisherman. To minimize the capacity of the battery, the fishing activities concept is also change into centralized fishing activities which the activities is centralized in an open sea and has the offshore building as the fishing base that has power station to recharge the batteries and cold storage to collect all the fishes. As the object to redesign, it is used 10 GT purse seine fishing vessel. As the results of the calculation, it gets the total battery capacity 6000 Ah for operation 11 hours ( 4 hours travel time, 6.5 hours fishing activities, and 0.5 hours break). Based on the technical and economic analysis, it can be concluded that the battery electric fishing vessel has a better revenue and fewer expenses than the diesel-powered fishing vessel.
\end{abstract}

Keywords— batteries, electric propulsion systems, fishing vessels, Natuna Sea.

\section{INTRODUCTION}

$\mathrm{N}$ atuna Sea is one of the places in Indonesia, which has a high potency of catching fish. The potency of catching fish in the Natuna Sea nearly reached one million tons per year. There are three fishes with the high potency in Natuna which are, Small Pelagic fish with a potency of 621,500 tons per year, Demersal fish with a potency of 334,800 tons per year, and Big Pelagic fish with a potency of 66,100 tons per year [1].

The weather condition of the Natuna Sea has been categorized as "Slight Sea" by BMKG, where the wave height of Natuna Sea never gets higher than 1.25 meters. The average of the wave height of Natuna Sea is about 0.5 meters with the range of the wind speed is from 6 knots up to 20 knots. It makes sea around Natuna Island is a safe place for the fisherman to catch fish on there.

Natuna Sea does surround by islands which have the majority of the people works as a fisherman. Natuna Island is one of the islands that located in the north of Natuna Sea. In 2015, there are 7,066 families of fisherman from around 20,401 total families in Natuna Island [2]. It means almost $35 \%$ of the people in Natuna Island does depend on the outcome of the fisherman [3].

The life of the Fisherman is relying on the price and the availability of fuel oil as the main energy of their boat, either for a main engine or generator to produce electricity [4]. As today, the price of fuel is not being subsided again by the government and the availability also getting rare in the future, the fisherman activities got involved and their revenue is getting lower each day [5]. Therefore, a fishing boat without using any fuel is needed to help the life of the fisherman in Indonesia, especially in Natuna Island.

Juniarko Prananda, Department of Marine Engineering, Sepuluh Nopember Institute of Technology, Surabaya 60111, Indonesia, Email: juniarko@ne.its.ac.id

Eddy Setyo Koenhardono, Department of Marine Engineering, Sepuluh Nopember Institute of Technology, Surabaya 60111, Indonesia, Email: eddy-koen@its.ac.id

Rivaldi Clarence Tjoa, Department of Marine Engineering, Sepuluh Nopember Institute of Technology, Surabaya 60111, Indonesia
A Fishing boat or Fishing vessel that using rechargeable batteries as the source of power onboard is one of the answers to deny the using of fuel oil on the fishing vessel [6]. So the idea is, the batteries can be recharged or switch when the fisherman is on the power station. The location of power station can be located either on the sea or land or both.

Considering the weight and the price of the batteries used on the ship is getting heavy and expensive if the size of the batteries is getting larger, then the idea is to make a fishing activity which centralized in an area. Those areas will have like offshore building which consists of the energy station (produce energy), fish tanks (stored catching fish), guard tower (observe the area), and living or accommodation room for the crews. This offshore building or aquaculture or energy station on the sea is becoming a place for the fisherman to depart and arrive for fishing activities. Later, for once in 3 days or a week, a large fishing vessel which also as a supply vessel will come to collect all the fish to bring it to the shore. So, by that, the small battery electric fishing vessel won't have a long operation time.

The location and the design of the offshore building or aquaculture won't be discussed in this research. This research will focus on designing and calculating the battery capacity of the small battery electric fishing vessel. The fishing vessel used in this research is the existed fishing vessel design and will be redesigning the propulsion system into electrical propulsion.

\section{METHOD}

\section{A. Statement of Problem}

This stage is an early stage to construct the research. In this stage, questions and problems are being prepared specifically in order to determine the specific objectives of this research. The content of the research is to overcome the statement of the problems mentioned earlier and it will be done by collecting some information about the problems. Therefore, the purpose of this research can be understood at this stage. 


\section{B. Literature Study}

Right after the problems is raised, a literature study is performed. In this stage, literature will be used to connect the problems with existing theories and facts from various sources. Since this research research is an implementation of many aspects discipline, various literature topics are required to be constructed into one project. The study of literature is done by reading papers, journals, research, media and literature books that relate and able to support this research.

\section{Collecting Data}

After literature study, the next stage is collecting data. Data collection is done by gathering information about the existed design of fishing vessel equal to $10 \mathrm{GT}$, electrical equipment specifications and requirements such as Induction motor, purse seine winch, windlass, radio navigation, etc. and also the fishing activities profiles to know the operation time.

\section{Resistance and Power Calculation}

In calculating the resistance and power needed for the electric motor, Maxsurf software will be used with the efficiency of propeller between $40-55 \%$. So after the data from the Maxsurf is out, it will be easier to select the Electric motor for the propulsion engine.

\section{E. Determination of Operation Profile}

In determining the operation profile, there will be some factors should be considered such as the radius of the fishing vessel will operate, time for setting and hauling the purse seine, time for searching the fish, and how many settings and hauling will be doing [7]. Those factors will be considered to choose the best operation profile, which has the long radius with many fishing activities and also operate in one day.

\section{F. Arrangement of Electrical Load}

Planning and arranging the electrical equipment will be doing at this stage. Besides planning the electrical equipment, there will be also the selection of the best electrical equipment which has the lowest electric consumption $^{[8]}$. And if the equipment can be operated manually, then it will be selected, in order to minimize the electrical consumption on the fishing vessel, so that the battery capacity needed can be minimized.

\section{G. Calculation of Electrical Load on Board}

At this stage, all the equipment which consume electricity will be calculated to know how much electricity needed on board, so that the battery can be calculated ${ }^{[9]}$. This calculation stage collects all equipment on board and lists them on voltage, power, current, operation time, and the last is the ampere-hour to know the battery capacity needed on the board.

\section{H. Calculation of Battery Capacity}

On this stage, the calculation of battery capacity need to install is performed. The steps are collecting all the electrical loads on the fishing vessel and the time estimated of all the electrical load will be consumed, then find out the ampere consumption for all electrical load and multiply them with the time consumed to get the battery capacity in ampere-hour ${ }^{[\mathbf{1 0}]}$. Last, adding some reserve capacity around $10 \%$ to $15 \%$ for the uncommon situation and for an emergency ${ }^{[11]}$.

\section{Calculation of Payload}

This stage is performing a calculation of payload to see if the battery is changing the payload or not. Calculating the payload will need some data such as weight displacement, construction weight, machinery weight except battery and DC motor, and moveable weight. These data will help to find the payload for each type of battery will select.

\section{J. Economic Calculation}

After knowing the battery capacity and types of battery that will be chosen, there will be an economic calculation to calculate the price to invest on the electrical propulsion and the operation cost of the electrical propulsion and diesel propulsion where later on will compare each other and showing which type of propulsion has the economic advantage ${ }^{[\mathbf{1 2}]}$. Besides that, there will be also a break-even calculation of the electrical propulsion to show in which year the money to invest in the battery electric fishing vessel will be paid off.

\section{K. Arrangement of Electric Propulsion on Fishing Vessel}

In this stage, designing the wiring diagram of the electrical load is performed. Not only that, it is also doing an arrangement of battery room. In designing and planning the wiring there are several factors which should be considered such as voltage needed, current flow, type of the current, and etc. Planning battery room also cannot just put them in the room, but should also consider the space available to do the replacement or maintenance of the equipment there.

\section{RESULTS AND DISCUSSION}

\section{A. Fishing Vessel Principal Dimension}

The fishing vessel used to redesign the propulsion system is a 10 GT fishing vessel with fishing equipment used is purse seine. The principal dimension of the fishing vessel can be seen on Table 1 .

TABLE 1. FISHING VESSEL PRINCIPAL DIMENSION

\begin{tabular}{lcc}
\hline Type of Ship & Fishing Vessel Purse Seine & \\
Length (Lwl)/ Length (Lpp) & $11.83 / 10$ & $\mathrm{~m}$ \\
Breadth (B) & 3 & $\mathrm{~m}$ \\
Height (H) & 1.3 & $\mathrm{~m}$ \\
Draught (T) & 0,9 & $\mathrm{~m}$ \\
Service Speed & 7 & knots \\
Block Coefficient & 0,435 & \\
Prismatic Coefficient & 0,519 & \\
Midship Area Coefficient & 0,838 & \\
\hline
\end{tabular}




\section{B. Resistance and Power Calculation}

In calculating the resistance by Maxsurf software, the power propulsion is calculated based on overall efficiency set at $50 \%$. It consists of propeller efficiency, transmission efficiency, and electrical efficiency. So the power describes on the Table 2 is the power of the electrical motor needed to produce thrust and accelerate the ship up to 7 knots.

\begin{tabular}{ccc} 
SHIP RESISTANCE AND POWER BASED ON MAXSURF SOFTWARE \\
\cline { 2 - 3 } $\begin{array}{c}\text { Speed } \\
\text { (knots) }\end{array}$ & $\begin{array}{c}\text { Holtrop } \\
\text { Resistance }(\mathrm{kN})\end{array}$ & $\begin{array}{c}\text { Electrical Motor } \\
\text { Power }(\mathrm{kW})\end{array}$ \\
\hline 0 & -- & -- \\
0,5 & 0,01 & 0 \\
1 & 0,03 & 0,03 \\
1,5 & 0,06 & 0,09 \\
2 & 0,09 & 0,19 \\
2,5 & 0,14 & 0,36 \\
3 & 0,2 & 0,61 \\
3,5 & 0,26 & 0,94 \\
4 & 0,34 & 1,39 \\
4,5 & 0,43 & 1,98 \\
5 & 0,55 & 2,82 \\
5,5 & 0,71 & 4,04 \\
6 & 0,92 & 5,65 \\
6,5 & 1,17 & 7,85 \\
7 & 1,58 & 11,36 \\
\hline
\end{tabular}

C. Determination of Operation Profile

1) Operational Time to Catch the Fish Using 10 GT

The fishing vessel is planned to have an operation in one day trip. Depart in the morning at 7 o'clock and goes from Aquaculture (fishing base) to the Fishing Ground which has distance about 14 NM from aquaculture. With the speed vessel about 7 knots, the time needed to be arriving at the fishing ground is about 2 hours.

Based on Fisherman's Workbook by J. Prado and P.Y. Dremiere, so the plan of the operational time of the fishing vessel will be like:

1. Searching $=30$ minutes

2. Setting-Hauling for fishing activities.

a. Setting the purse seine $=10$ minutes.

b. Pull in (Hauling) the purse seine $=25$ minutes (AC motor off)

3. Fishing activities (setting-hauling) is done about 6 times, So total use of AC Motor $=8$ hours ( 4 hours fishing activities +4 hours voyage)

4. Use of Purse Seine machine 25 minutes x 6 times $=2.5$ hours

2) Lunch break

Time for lunch break is about half an hour ( 0.5 hour)

From those times above, it can determine the total operation time, which can be calculated like:

Operation time $=$ Departure time + fishing activities + lunch break + arriving time
Operation time $=2$ hours +6.5 hours +0.5 hour +2 hours

Operation time $=11$ hours

So the total operation time of the fishing vessel is 11 hours, and because the departure time is 7 AM then the time the fishing vessel finish or arrive again in aquaculture is at $6 \mathrm{PM}$.

\section{Calculation of Electrical Load on the Board}

1) Selection of Electric Motor

From the Table 2, it can be concluded that the power needed to speed up the fishing vessel up to 7 knots is $11,36 \mathrm{~kW}$. Then, to select the electrical motor power, it just picks the motor which produces the power minimum $11,36 \mathrm{~kW}$ and the selected electric motor is AC motor VM 160L which produce power up to 12,5 $\mathrm{kW}$.

AC Motor specification:

Type : VM 160L

RPM : $2930 \mathrm{RPM}$

Power : : 12,5 kW

Voltage : $220 \mathrm{~V}$

Weight $: 111,5 \mathrm{~kg}$

2) Electrical Load on the Board

The electrical load on board is a load of electricity needed to power up all devices and equipment which need electrical power to operate ${ }^{[14]}$. The devices and equipment which need electrical power to supply can be seen in the Table 3 . 
TABLE 3.

ELECTRICAL LOAD ON BOARD

\begin{tabular}{lcccccc}
\hline \multicolumn{1}{c}{ Equipment } & unit(s) $\begin{array}{c}\text { Power } \\
(\mathrm{kW})\end{array}$ & $\begin{array}{c}\text { Voltage } \\
\text { (volt) }\end{array}$ & $\begin{array}{c}\text { Current } \\
\text { (Ampere) }\end{array}$ & $\begin{array}{c}\text { Operation time } \\
\text { (hours) }\end{array}$ & $\mathrm{kWh}$ \\
\hline Propulsion AC Motor* & 1 & 15,00 & 380 & 39,47 & 8,00 & 120,00 \\
Purse Seine motor (AC)* & 1 & 5,00 & 380 & 13,16 & 3,33 & 16,67 \\
Anchor winch motor & 1 & 1,50 & 24 & 62,50 & 0,10 & 0,15 \\
Navigation Lamp & 5 & 0,24 & 24 & 10,00 & 2,00 & 2,40 \\
Emergency Lamp & 1 & 0,06 & 24 & 2,50 & 1,00 & 0,06 \\
Radio Navigation & 1 & 0,025 & 24 & 1,04 & 11,00 & 0,28 \\
Fish finder & 1 & 0,006 & 24 & 0,25 & 9,00 & 0,05 \\
\hline & \\
&
\end{tabular}

3) Selection of Battery Capacity

According to the Table 3, the total power needed is $133,99 \mathrm{kWh}$ to cover all the electrical load on board. So the battery will be selected with minimum capacity about 5973,90 Ah, which get from dividing the $\mathrm{kWh}$ with the battery voltage. Besides the capacity, in selecting the battery there will be other factors need to look up such as weight, dimensions, and price. Table 4 will show the batteries can be selected as the energy source on the fishing vessel.

TABLE 4.

BATTERY NEEDED ON ELECTRICAL LOAD

\begin{tabular}{|c|c|c|c|c|c|c|c|c|}
\hline \multirow[b]{2}{*}{ No } & \multirow[b]{2}{*}{ Name } & \multirow{2}{*}{$\begin{array}{l}\text { Capacity } \\
\text { (AH) }\end{array}$} & \multirow{2}{*}{$\begin{array}{l}\text { Voltage } \\
\text { (Volt) }\end{array}$} & \multirow{2}{*}{$\begin{array}{l}\text { Weight } \\
(\mathrm{kg})\end{array}$} & \multicolumn{4}{|c|}{ Amount of Batteries } \\
\hline & & & & & Series & s Parallel & Total & $\begin{array}{c}\text { Weight tota } \\
(\mathrm{kg})\end{array}$ \\
\hline & $\begin{array}{l}\text { Fortune } 100 \mathrm{Ah} 3,2 \mathrm{~V} 3 \mathrm{C} \\
\text { Type: Li-Ion }\end{array}$ & 100 & 3 & 3 & 8 & 60 & 480 & 1440 \\
\hline 2 & $\begin{array}{l}\text { RB24V100 } \\
\text { Type: Li-Ion }\end{array}$ & 100 & 24 & 27,7 & 1 & 60 & 60 & 1662 \\
\hline 3 & $\begin{array}{l}\text { Bright Star 120Ah 3,2V 3C } \\
\text { Type: Li-Ion }\end{array}$ & 120 & 3 & 2,8 & 8 & 50 & 400 & 1120 \\
\hline 4 & $\begin{array}{l}\text { Deep Blue Sealed } \\
\text { Type: Lead Acid }\end{array}$ & 220 & 24 & 77,1 & 1 & 28 & 28 & 2159 \\
\hline 5 & $\begin{array}{l}\text { Bright Star } 220 \mathrm{Ah} 3,2 \mathrm{~V} 3 \mathrm{C} \\
\text { Type: Li-Ion }\end{array}$ & 220 & 3 & 6 & 8 & 28 & 224 & 1344 \\
\hline & $\begin{array}{l}\text { EV LiFePO4 Battery Pack } \\
\text { Type: Li-Ion }\end{array}$ & 10 & 24 & 2,4 & 1 & 600 & 600 & 1440 \\
\hline
\end{tabular}

\section{E. Calculation of Payload}

A payload can determine by subtracting the new DWT (Dead Weight Tonnage) with the weight of the moveable items. The DWT can get by subtracting the displacement with the LWT (Light Weight Tonnage), where the LWT can be got from adding the construction weight with the machinery weight.

1) Determining the Construction Weight by using the LWT of Mechanical Propulsion

- Calculation of Weight Displacement

The Weight displacement of the fishing vessel is can be get from multiplying the Lwl, T, B, Cb, and $\rho_{\text {seawater. }}$ The result is 14,05 ton.

\section{- Calculation of DWT}

Based on the early planning for the fishing vessel, it can be known that the DWT of the fishing vessel is 5,4 ton. The DWT is consist of Payload and Weight of the moveable items, where the payload itself is 3,9 ton and the rest is the weight of the moveable items.

The weight of the moveable items is consists of fresh waters, foods, crews and provisions, fuel oils, and the reserves.

$\circ$ Weight of fresh waters

The need of fresh water on board is between 5-

25 liters/person/day. It is picked 12 liters/person/day.

Cfwd $=12 \mathrm{l} /$ person/day
Operation time $(\mathrm{t})=5$ days

Total crew $(\mathrm{n}) \quad=5$ persons

$\mathrm{W}_{\text {fresh water }}=\mathrm{n} \times \mathrm{t} \times \mathrm{Cfwd}$

$=5 \times 5 \times 12 / 1000$

$=0,3$ ton

So the weight of fresh water needed on board is 0,3 ton.

$\circ$ Weight of foods

The need of foods on board is between 4-6 $\mathrm{kg} /$ person/day. It is picked $5 \mathrm{~kg} /$ person $_{\text {/day }}$.

$\mathrm{W}_{\text {foods }}=5 \mathrm{~kg} /$ person $/{ }^{\text {day }} \times 5$ persons $\times 5$ days $/$ 1000 $=0,125$ ton

So the weight of foods on board is 0,125 ton. $\circ$ Weight of crews and provisions

The weight of crews can be estimated between $60-75 \mathrm{~kg} /$ person and the provision is about 1 $\mathrm{kg} /$ person $/$ day. It is picked $75 \mathrm{~kg} /$ person in 5 days operation.

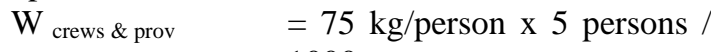
1000 $=0,375$ ton.

○ Reserve Weight

Reserve weight is for unintentional things and things in store. It can be estimate about $0,45 \%$ from weight displacement.
Reserve weight
$=0,45 \% \times \Delta$
$=0,0625$ ton
$\circ$ Fuel oils weight $\quad=0,6375$ ton 
So the total weight of moveable items are 1,5 ton.

- Calculation of Construction Weight

In determine the LWT, it can be get by subtracting weight displacement with DWT.

LWT $=\Delta-$ DWT

$$
=14,05-5,4=8,65 \text { ton }
$$

By knowing the value of LWT, the weight of construction can be calculated by subtracting LWT with the weight of machineries.
Mach weight
$=0,5$ ton (main engine + others)
Cons weight
$=\mathrm{LWT}-$ machineries weight
$=8,65-0,5$
$=8,15$ ton

2) Calculation of Payload using Battery Electric
Propulsion

- Calculation of LWT

LWT in battery electric propulsion is different with the mechanical propulsion. The difference is located in the machineries weight. The machineries weight on battery electric propulsion are consist of AC motor, batteries, and other machineries.
LWT
$=$ Cons weight + Mach weight
Cons. weight
$=8,15$ ton
AC motor weight
$=0,112$ ton
Other machinery
$=0,2$ ton
Batteries weight can be seen on Table 4 .

So for the LWT variation result can be seen on Figure 1.

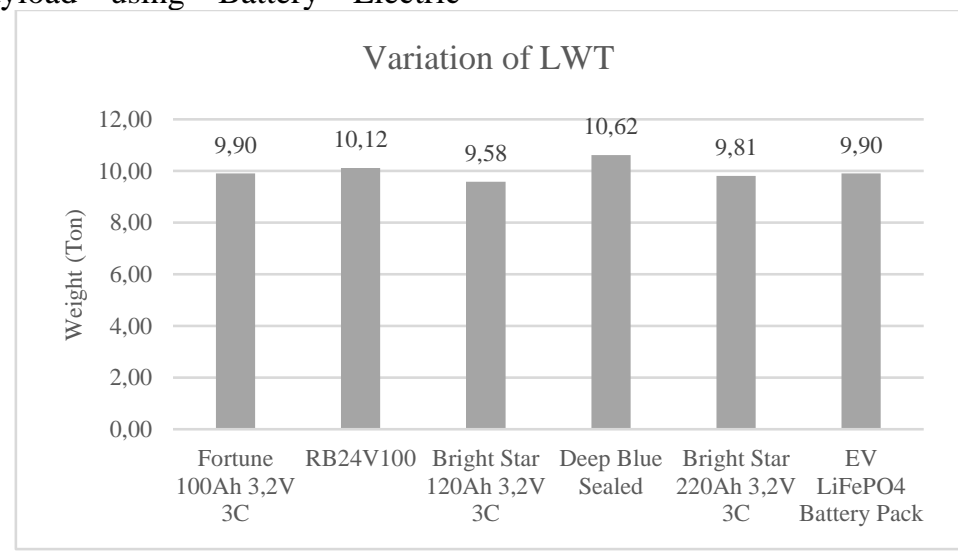

Figure. 1. Variation of LWT on each kind of batteries

- Calculation of Payload

Payload can be achieve from DWT subtract weight of moveable items. DWT itself can be get by subtracting weight displacement with LWT.

○ Weight of moveable items

It is consist of fresh water weight, food weight, crew and provision weight and reserve weight. $\mathrm{W}_{\text {fresh water }}=15^{\text {liters }} /$ person $/{ }^{\text {day }} \times 5$ persons $\times 1$ day / 1000 $=0,075$ ton

$$
\begin{aligned}
\mathrm{W}_{\text {food }} & =5 \mathrm{~kg} / \text { person }^{\text {day }} \times 5 \text { persons x } 1 \text { day } / 1000 \\
& =0,025 \text { ton } \\
\mathrm{W}_{\text {Crew \& prov }} & =71 \mathrm{~kg} / \text { person } \times 5 \text { persons } / 1000 \\
& =0,355 \text { ton } \\
\mathrm{W}_{\text {reserve }} & =0,06 \text { ton } \\
\mathrm{W}_{\text {moveable }} & =0,075+0,025+0,355+0,06 \\
& =0,52 \text { ton }
\end{aligned}
$$

So for the Payload variation result can be seen on Figure 2.

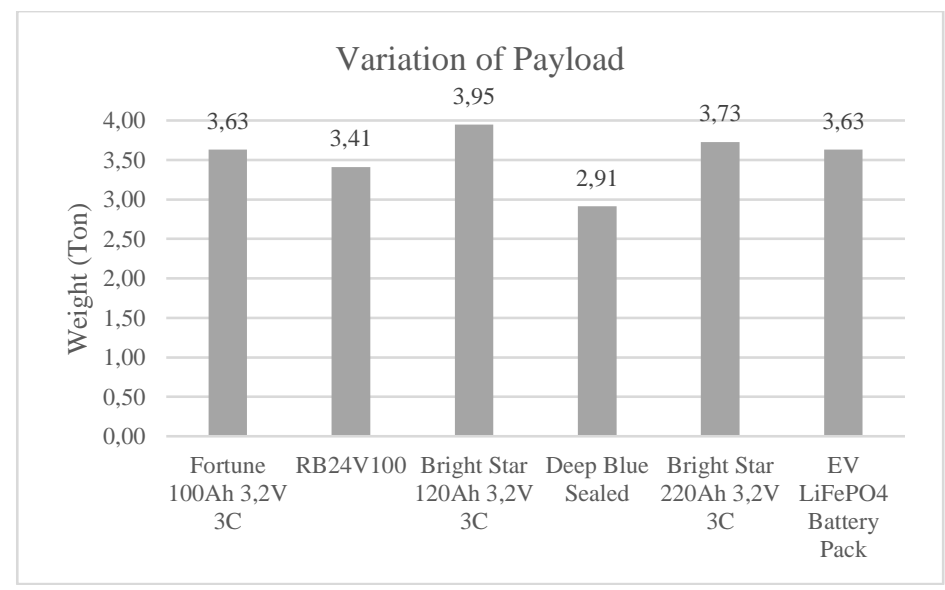

Figure. 2. Variation of payload on each type of batteries

\section{F. Economic Calculation}

In calculation of economic, it will include some expenses such as, new build fishing vessel cost both use mechanical propulsion and electrical propulsion, operation cost both mechanical propulsion and electrical propulsion, and a comparison of both mechanical propulsion and electrical propulsion in the term of expenses each year up to 29 years to see which one is better or cheaper in expenses.

1) New Shipbuilding Cost

In calculating the shipbuilding cost, it uses an estimation where the estimation of new shipbuilding 
using mechanical propulsion can be seen on the Table

5.

TABLE 5.

NEW SHIPBUILDING COST USING MECHANICAL PROPULSION

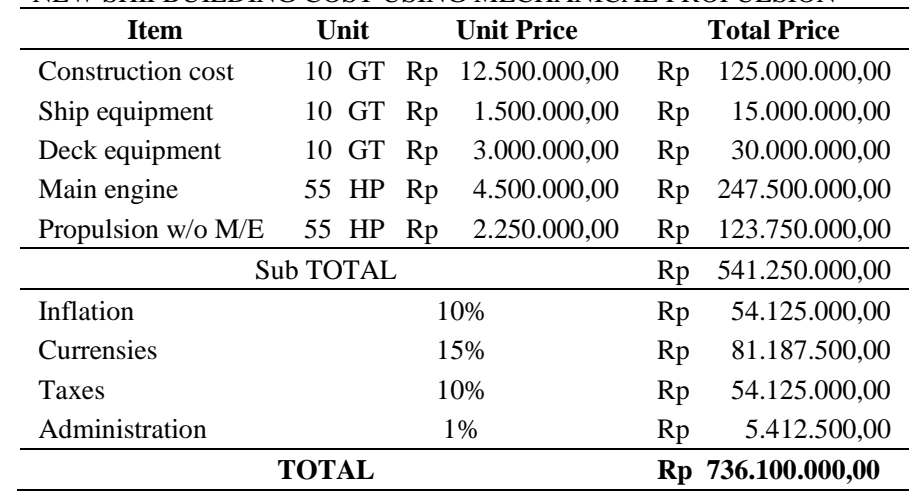

For the new shipbuilding cost without mechanical propulsion, it can be determined by the same method of estimation but without using the mechanical propulsion. The calculation is described in the Table 6.

TABLE 6.

NEW SHIPBUILDING COST WITHOUT PROPULSION

\begin{tabular}{|c|c|c|c|c|}
\hline Item & Unit & Unit Price & & Total Price \\
\hline Construction cost & $10 \mathrm{GT}$ & Rp 12.500.000,00 & $\mathrm{Rp}$ & $125.000 .000,00$ \\
\hline Ship equipment & $10 \mathrm{GT}$ & $\mathrm{Rp} \quad 1.500 .000,00$ & $\mathrm{Rp}$ & $15.000 .000,00$ \\
\hline Deck equipment & $10 \mathrm{GT}$ & $3.000 .000,00$ & $\mathrm{Rp}$ & $30.000 .000,00$ \\
\hline Propulsion w/o M/E & $55 \mathrm{HP}$ & $2.250 .000,00$ & $\mathrm{Rp}$ & $123.750 .000,00$ \\
\hline \multicolumn{3}{|c|}{ Sub TOTAL } & $\mathrm{Rp}$ & $293.750 .000,00$ \\
\hline Inflation & \multicolumn{2}{|r|}{$10 \%$} & $\mathrm{Rp}$ & $29.375 .000,00$ \\
\hline Currensies & \multicolumn{2}{|r|}{$15 \%$} & $\mathrm{Rp}$ & $44.062 .500,00$ \\
\hline Taxes & \multicolumn{2}{|r|}{$10 \%$} & $\mathrm{Rp}$ & $29.375 .000,00$ \\
\hline Administration & \multicolumn{2}{|r|}{$1 \%$} & $\mathrm{Rp}$ & $2.937 .500,00$ \\
\hline \multicolumn{3}{|c|}{ TOTAL } & $\mathbf{R p}$ & $399.500 .000,00$ \\
\hline
\end{tabular}

2) Electrical Propulsion Cost

In calculating electrical propulsion cost, at first, it must be chosen which battery will be used as the electric source on the board. In choosing or selecting the battery, it comes to two factors which are the payload of the fishing vessel and the cost of the batteries. In the Table 7, it will display the battery total cost.

TABLE 7.

BATTERY COST

\begin{tabular}{|c|c|c|c|c|}
\hline No & Name & $\begin{array}{c}\text { Total of } \\
\text { Batteries }\end{array}$ & Unit Price & Total Price \\
\hline 1 & Fortune 100Ah 3,2V 3C & 480 & 108,00 & $700.047 .878,40$ \\
\hline 2 & RB24V100 & 60 & Rp 4.375.000,00 & Rp 2.062.500.000,00 \\
\hline 3 & Bright Star 120Ah 3,2V 3C & 400 & 129,00 & $696.806 .916,00$ \\
\hline 4 & Deep Blue Sealed & 28 & Rp 8.021.400,00 & 224.599.200,00 \\
\hline 5 & Bright Star 220Ah 3,2V 3C & 224 & $\$ \quad 237,00$ & $716.900 .882,88$ \\
\hline 6 & EV LiFePO4 Battery Pack & 600 & 191,00 & Rp 1.547.559.546,00 \\
\hline \multicolumn{2}{|r|}{ Currency Converter } & & & \\
\hline$\$$ & Rp $\quad 13.504,01$ & & & \\
\hline
\end{tabular}

So by comparing and analyzing the payload on the Figure 2 and the battery cost of the Table 7 for the six batteries, it will select the battery which has nearly the same or more payload with the previous design and has a lower cost among others. The selected battery is: Name

Type

Capacity

Voltage

Max discharge current : $200 \mathrm{~A}$

Total Batteries $\quad: 400$ pieces

Total Weights $\quad: 1120 \mathrm{~kg}$
Total Price

: Rp. 696.806.916

Besides the battery, for electrical propulsion, there are other items that should be bought and installed on the board. Table 4.6-4 showing the total investment should be paid for building a new ship using electrical propulsion. 
TABLE 8.

NEW SHIPBUILDING COST USING ELECTRIC PROPULSION

\begin{tabular}{|c|c|c|c|c|c|}
\hline \multirow{2}{*}{$\begin{array}{c}\text { No } \\
1\end{array}$} & Item & \multirow{2}{*}{$\begin{array}{l}\text { Unit } \\
400\end{array}$} & Unit Price & \multicolumn{2}{|c|}{ Total Price } \\
\hline & Batteries & & 129,00 & $\mathrm{Rp}$ & $696.806 .916,00$ \\
\hline 2 & AC Motor & 1 & Rp $15.403 .000,00$ & $\mathrm{Rp}$ & $15.403 .000,00$ \\
\hline 3 & DC-AC Inverter & 1 & $£ \quad 622,80$ & $\mathrm{Rp}$ & $11.262 .590,64$ \\
\hline 4 & Battery Charger & 25 & 156,00 & $\mathrm{Rp}$ & $52.665 .639,00$ \\
\hline 5 & BMS & 25 & 9,60 & $\mathrm{Rp}$ & $3.240 .962,40$ \\
\hline 6 & $\begin{array}{l}\text { Shipbuilding cost } \\
\text { without propulsion }\end{array}$ & n $\quad 1$ & Rp 399.500.000,00 & $\mathrm{Rp}$ & $399.500 .000,00$ \\
\hline \multicolumn{4}{|c|}{ INVESTMENT TOTAL } & \multicolumn{2}{|c|}{ Rp 1.178.879.108,04 } \\
\hline \multicolumn{3}{|c|}{ Currency Converter } & & & \\
\hline$\$$ & $1,00 \quad \mathrm{Rp}$ & $13.504,01$ & & & \\
\hline$£$ & 1,00 & $18.083,80$ & & & \\
\hline
\end{tabular}

3) Operation Costs

In calculating the operation cost of the fishing vessel either use diesel or electric propulsion, it should have the same operational profile, so that the comparison is valid. As mentioned on subchapter 4.3 about the operation time or profile, here the calculation of operation cost.

- Diesel Propulsion

The operation cost of diesel propulsion is about the consumption of the fuel. The fuel consumption cost can be calculated by multiplying the fuel consumption in a year with the price of the Diesel fuel that the Indonesian fisherman bought. To know the fuel consumption in a year, here is the calculation.

Fuel cons. a year $=$ fuel consumption rate $\mathrm{x}$ operation time $\mathrm{x}$ day of operation in a year

Fuel cons. a year $=12,2$ liter/hour x 8 hours x 336 days

Fuel consumption in a year $=32.793,6$ liters

So, the operation cost in a year for the diesel propulsion is:

Operation cost $=$ Fuel consumption in a year $\mathrm{x}$ price of fuel

Operation cost $=32.793,6$ liters $\times 7.600 \mathrm{IDR} /$ liter

Operation cost $=\operatorname{Rp} 249.231 .360,00 /$ year

- Electric Propulsion

The operation cost of electric propulsion is about the amount of electric power used to recharge the batteries. At first, it must know which category in PLN is the cost of consumption by calculating the electric power needed. Here it is the calculation of the electric power needed from PLN:

$\begin{array}{lll}\text { Voltage } & =24 & \mathrm{~V} \\ \text { Load total } & =6000 & \mathrm{Ah} \\ \text { Charging time } & =12 & \text { hour }\end{array}$

$$
\begin{array}{ll}
\text { Current } & =\text { Load total } / \text { charging time } \\
& =6000 \mathrm{Ah} / 12 \mathrm{~h}=500 \mathrm{~A} \\
\text { Electric Power } & =\text { Voltage } \times \text { Current } \\
& =24 \mathrm{~V} \times 500 \mathrm{~A} \\
& =12.000 \mathrm{VA}=12 \mathrm{kVA}
\end{array}
$$

So from the electric power needed from PLN, it can determine the cost of the electric power consumed.

From the PLN tariff adjustment, it can know that the cost category is R-3/TR with power limitation from 6,6 kVA - $200 \mathrm{kVA}$ and the cost is Rp. $1.467,28 / \mathrm{kWh}$.

By knowing the cost of the electric power, it can calculate the operation cost of the electric propulsion, here is the calculation.

$$
\begin{array}{ll}
\text { Total power } & =\mathrm{V} \times \mathrm{I} \times \text { Power factor } \\
& =24 \mathrm{~V} \times 500 \mathrm{~A} \times 0,8 \\
& =9.600 \mathrm{~W}=9,6 \mathrm{~kW} \\
\text { Power needed } & =\text { Total Power } \times \text { Charging time } \\
& =9,6 \mathrm{~kW} \times 12 \text { hour } \\
& =115,2 \mathrm{kWh} \\
\text { Operation cost } & =\text { Power needed } \times \text { electric cost } \\
& \text { x total charge in year } \\
& =115,2 \mathrm{kWh} \times 1.467,28 \\
& \text { IDR } / \mathrm{kWh} \times 336 \\
& =\mathrm{Rp} 56.794 .300,42 / \text { year } \\
& =\mathrm{Rp} 57.000 .000,00 / \text { year }
\end{array}
$$

So the operation cost for diesel propulsion in a year is $\mathrm{Rp} 249.231 .360,00$, and electric propulsion in a year is Rp. 57.000.000,00.

Besides, the cost of propulsion, there are also others operation cost, such as food, ice, crew salary, and maintenance cost. Table 9 shows the total expenses for operation of diesel-powered fishing vessel and battery electric fishing vessel. 
TABLE 9.

EXPENSES FOR OPERATE THE FISHING VESSEL

\begin{tabular}{|c|c|c|c|c|c|}
\hline \multicolumn{3}{|c|}{ DIESEL-POWERED FISHING VESSEL } & \multicolumn{3}{|c|}{ BATTERY ELECTRIC FISHING VESSEL } \\
\hline \multicolumn{3}{|c|}{ ICE } & \multicolumn{3}{|c|}{ ICE } \\
\hline Ice needed in a day & 1,11 & Ton & Ice needed in a day & 1,11 & Ton \\
\hline Ice price $/ \mathrm{kg}$ & $\mathrm{Rp}$ & $1.400,00$ & Ice price $/ \mathrm{kg}$ & $\mathrm{Rp}$ & $1.400,00$ \\
\hline Ice cost for one year & $\mathrm{Rp}$ & $522.144 .000,00$ & Ice cost for one year & $\mathrm{Rp}$ & $522.144 .000,00$ \\
\hline \multicolumn{3}{|c|}{ FOOD } & \multicolumn{3}{|c|}{ FOOD } \\
\hline Food needed in a day & 15 & Portion & Food needed in a day & 15 & Portion \\
\hline Food price /portion & $\mathrm{Rp}$ & $12.500,00$ & Food price /portion & $\mathrm{Rp}$ & $12.500,00$ \\
\hline Food cost in a year & $\mathrm{Rp}$ & $63.000 .000,00$ & Food cost in a year & $\mathrm{Rp}$ & $63.000 .000,00$ \\
\hline \multicolumn{3}{|c|}{ CREW SALARY } & \multicolumn{3}{|c|}{ CREW SALARY } \\
\hline Total crew & 10 & Person & Total crew & 10 & Person \\
\hline Crew salary & $\mathrm{Rp}$ & $2.500 .000,00$ & Crew salary & $\mathrm{Rp}$ & $2.500 .000,00$ \\
\hline Crew salary in a year & $\mathrm{Rp}$ & $300.000 .000,00$ & Crew salary in a year & $\mathrm{Rp}$ & $300.000 .000,00$ \\
\hline \multicolumn{3}{|c|}{ MAINTENANCE } & \multicolumn{3}{|c|}{ MAINTENANCE } \\
\hline Maintenance cost & $\mathrm{Rp}$ & $58.943 .955,40$ & Maintenance cost & $\mathrm{Rp}$ & $58.943 .955,40$ \\
\hline \multicolumn{3}{|c|}{ FUEL } & \multicolumn{3}{|c|}{ ELECTRICAL } \\
\hline Fuel needed /day & 97,6 & liters & Electric needed /day & 115,2 & KWh \\
\hline Fuel price /litre & $\mathrm{Rp}$ & $7.600,00$ & Electric price $/ \mathrm{kWh}$ & $\mathrm{Rp}$ & $1.467,28$ \\
\hline Fuel cost in a year & $\mathrm{Rp}$ & $249.231 .360,00$ & Electric cost in a year & $\mathrm{Rp}$ & $56.794 .300,42$ \\
\hline TOTAL EXPENSES a year & Rp 1. & $.193 .319 .315,40$ & TOTAL EXPENSES a year & Rp 1.0 & $.000 .882 .255,82$ \\
\hline
\end{tabular}

\section{4) Loan Repayment}

Beside all the expenses from the Table 9, actually there is additional cost need to pay which called loan repayments. Loan repayments is a cost need to pay through the loan activities which happened before, in this case is the loan to build the fishing vessel. Loan repayments value is depend on the amount of money borrowed, time to repay, and the interest. Table 10 will show the total loan repayment per year for the dieselpowered fishing vessel and the battery electric fishing vessel.

TABLE 10.

TOTAL LOAN REPAYMENT PER YEAR

\begin{tabular}{lcc}
\multicolumn{3}{c}{ Loan Repayment (Battery Electric Fishing Vessel) } \\
\hline Total Loan & $\mathrm{Rp}$ & $1.178 .761 .220,13$ \\
Total Loan Interest (10\%/year) & $\mathrm{Rp}$ & $117.876 .122,01$ \\
Total Inflation (0,19\%/year) & $\mathrm{Rp}$ & $2.239 .646,32$ \\
Total Interest + Inflation (/year) & $\mathrm{Rp}$ & $120.115 .768,33$ \\
Target repayment (years) & & 10 \\
Total Repayment w/o interest (/year) & $\mathrm{Rp}$ & $117.876 .122,01$ \\
\hline Total Loan Repayment (/year) & $\mathrm{Rp}$ & $\mathbf{2 3 7 . 9 9 1 . 8 9 0 , 3 4}$ \\
\hline \multicolumn{3}{c}{ Loan Repayment (Diesel-Powered Fishing Vessel) } \\
\hline Total Loan & $\mathrm{Rp}$ & $736.026 .390,00$ \\
Total Loan Interest (10\%/year) & $\mathrm{Rp}$ & $73.602 .639,00$ \\
Total Inflation (0,19\%/year) & $\mathrm{Rp}$ & $1.398 .450,14$ \\
Total Interest + Inflation (/year) & $\mathrm{Rp}$ & $75.001 .089,14$ \\
Target repayment (years) & & 10 \\
Total Repayment w/o interest (/year) & $\mathrm{Rp}$ & $73.602 .639,00$ \\
\hline Total Loan Repayment (/year) & $\mathrm{Rp}$ & $\mathbf{1 4 8 . 6 0 3 . 7 2 8 , 1 4}$ \\
\hline
\end{tabular}

5) Expenses Comparison of Diesel-Powered and Battery Electric Fishing Vessel [2]

Based on all calculation above, it can be presented in a graph which shows the expenditure comparison between diesel-powered fishing vessel and battery electric fishing vessel each year for 29 years. The Figure 3 shows the expenditure comparison between diesel and electric propulsion. 


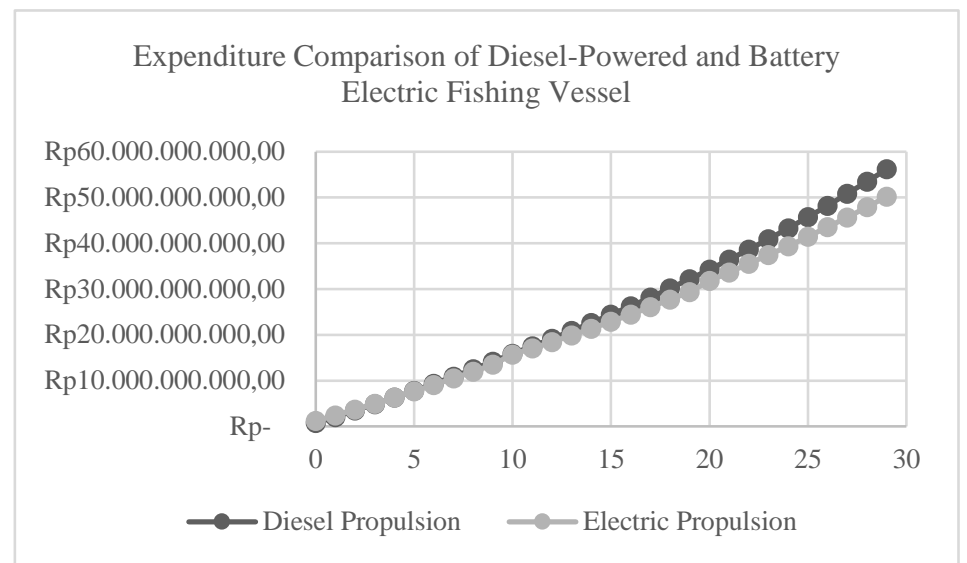

Figure. 3. Expenditure comparison of Diesel-Powered and Battery Electric Fishing Vessel

In Figure 3 for electric propulsion it is shown that in the 10th and 20th year of operation there is some unusual rise of the graph. Because in that year, there is an expense of buying new batteries in order to change the old batteries that happened to be at the end of the lifetime.

Based on Figure 3 also can be concluded that using an electric propulsion has a bigger investment than diesel propulsion, but in the end of fishing vessel lifetime, in this case, 29 years, the electric propulsion has a lower expense than diesel propulsion up to 3 billion Indonesian Rupiah (IDR). So, it can say that the electric propulsion use in this fishing vessel is better than diesel propulsion in the term of expenses.
6) BEP (Break Even Point) Analysis

Break Even Point is a point which has a condition of the total income and total expenses is the same or equal. This point has an important role in determining if the investment is a good investment or not, because this point tells about where the time when all the investment is getting paid off ${ }^{[13]}$.

In analyzing the Break Even Point, it is need to know the price to invest, cost for operating the fishing vessel and also needs to know the income from doing fishing. The Table 11 shows the total income from operating the diesel-powered fishing vessel and the battery electric fishing vessel.

TABLE 11.

TOTAL INCOME A YEAR

\begin{tabular}{lcc}
\multicolumn{3}{c}{ TOTAL INCOME A YEAR } \\
\hline Cargo space & 6 & $\mathrm{~m}^{3}$ \\
Stowage rate & 2,7 & $\mathrm{~m}^{3} /$ tonne of fish \\
ton of fish & 2,22 & ton \\
ton of ice & 1,11 & ton \\
Payload & 3,33 & ton \\
Price of fish & $\mathrm{Rp}$ & $2.000,00$ \\
Income in one day & $\mathrm{Rp}$ & $4.400 .000,00$ \\
Income in a month & $\mathrm{Rp}$ & $123.200 .000,00$ \\
\hline Income in a year & $\mathrm{Rp}$ & $1.478 .400 .000,00$ \\
\hline
\end{tabular}

From the Table 5, 8, 9, 10, and 11, it can derive and make an accumulation of the income and expenses each year for 10 years as shown in the Table 12, Figure 4 and Figure 5.

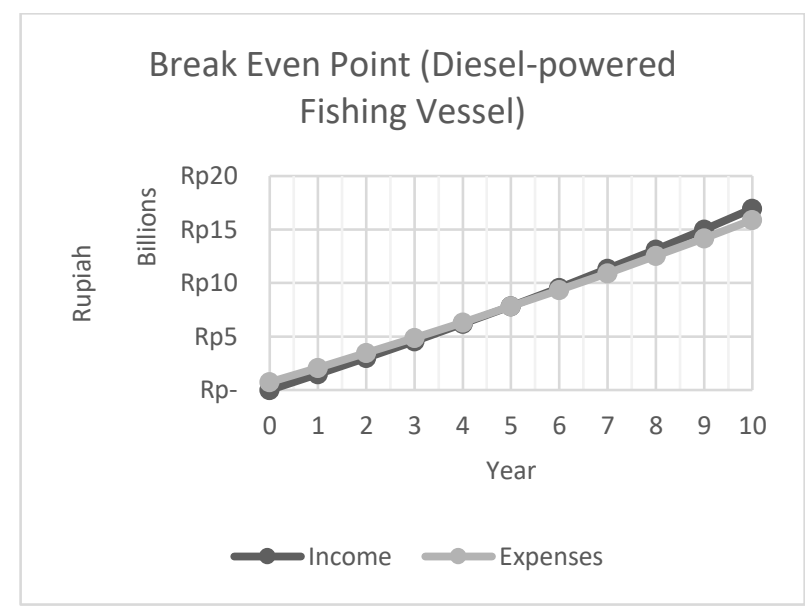

Figure. 4. Break Even Point graph (Diesel-powered fishing vessel) 
TABLE 12

\begin{tabular}{|c|c|c|}
\hline \multicolumn{3}{|c|}{ Diesel-powered Fishing Vessel } \\
\hline Year & Income & Expenses \\
\hline 0 & $\mathrm{Rp}$ & Rp $1.178 .879 .108,04$ \\
\hline 1 & $\mathrm{Rp} \quad 1.478 .400 .000,00$ & $\operatorname{Rp} 2.417 .753 .254,20$ \\
\hline 2 & $\mathrm{Rp} 3.001 .152 .000,00$ & $\operatorname{Rp} 3.686 .653 .868,04$ \\
\hline 3 & $\operatorname{Rp} 4.569 .586 .560,00$ & Rp $4.986 .481 .743,58$ \\
\hline 4 & $\begin{array}{ll}\mathrm{Rp} & 6.185 .074 .156,80\end{array}$ & Rp $6.318 .164 .698,68$ \\
\hline 5 & Rp $7.849 .026 .381,50$ & Rp $7.682 .658 .385,72$ \\
\hline 6 & $\mathrm{Rp} \quad 9.562 .897 .172,95$ & Rp $9.080 .947 .126,66$ \\
\hline 7 & Rp 11.328.184.088,14 & Rp 10.514.044.773,12 \\
\hline 8 & $\operatorname{Rp} 13.146 .429 .610,78$ & Rp 11.982.995.592,26 \\
\hline 9 & Rp 15.019.222.499,11 & Rp 13.488.875.179,27 \\
\hline 10 & Rp 16.948.199.174,08 & Rp $15.729 .598 .313,17$ \\
\hline \multicolumn{3}{|c|}{ Battery Electric Fishing Vessel } \\
\hline Year & Income & Expenses \\
\hline 0 & $\mathrm{Rp}$ & $\begin{array}{ll}\mathrm{Rp} & 736.100 .000,00\end{array}$ \\
\hline 1 & $\mathrm{Rp} \quad 1.478 .400 .000,00$ & $\operatorname{Rp} 2.078 .023 .043,54$ \\
\hline 2 & $\mathrm{Rp} 3.001 .152 .000,00$ & Rp 3.455.745.666,55 \\
\hline 3 & $\operatorname{Rp} 4.569 .586 .560,00$ & $\operatorname{Rp} 4.870 .341 .856,40$ \\
\hline 4 & $\operatorname{Rp} \quad 6.185 .074 .156,80$ & $\operatorname{Rp} \quad 6.322 .917 .820,10$ \\
\hline 5 & Rp 7.849.026.381,50 & Rp 7.814.612.950,87 \\
\hline 6 & Rp $\quad 9.562 .897 .172,95$ & $\begin{array}{ll}\text { Rp } & 9.346 .600 .823,72\end{array}$ \\
\hline 7 & Rp 11.328.184.088,14 & $\operatorname{Rp} 10.920 .090 .220,91$ \\
\hline 8 & Rp 13.146.429.610,78 & $\operatorname{Rp} 12.536 .326 .188,17$ \\
\hline 9 & Rp 15.019.222.499,11 & Rp 14.196.591.122,60 \\
\hline 10 & $\operatorname{Rp} 16.948 .199 .174,08$ & $\operatorname{Rp} 15.902 .205 .893,23$ \\
\hline
\end{tabular}

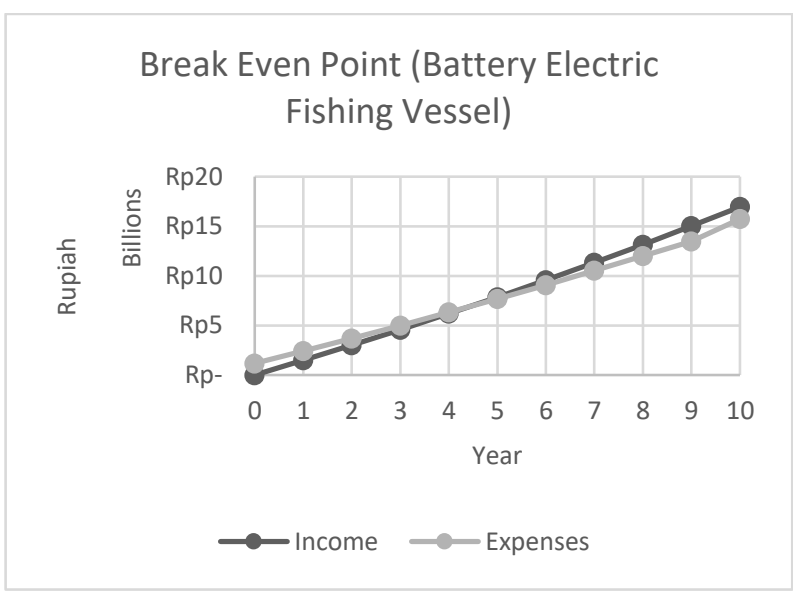

Figure. 5. Break Even Point graph (Battery Electric Fishing Vessel)

As shown in the Figure 4 and 5, between income and expenses has an intersection on $4^{\text {th }}$ year of operation. So, it means that the investment of diesel-powered fishing vessel and battery electric fishing vessel will pay off in the 4th year of operation. In Figure 5, in the $10^{\text {th }}$ year, there is a sudden rise of expenses happened because of buying new batteries to replace the old one.

7) Internal Rate of Return (IRR) Analysis

Internal Rate of Return is the value that show the investor the annual growth rate of an investment. The value of IRR is related with the present value, because the goal of IRR is to find the rate that makes the present value of the sum of annual cash inflows equal to initial net cash outflow for the investment ${ }^{[15]}$.

By knowing the net cash flow which is calculated by subtracting the cash inflows and outflows each year, the value of Present value can be calculated by dividing the net cash flow with the sum of one and discount rate rise to the power of time period. The present value later on, will be used to calculate the IRR by using IRR formula in Microsoft excel.

The result of IRR for diesel-powered fishing vessel is $13,9 \%$ and for battery electric fishing vessel is
$14,1 \%$. It means, in the side of investor also, the battery electric fishing vessel is better to invest than diesel-powered fishing vessel. In the case of comparing it with the loan interest which is about $10 \%$, this battery electric fishing vessel is a good investment project, because has higher value.

G. Arrangement of Electric Propulsion on Fishing Vessel Electrical wiring on this fishing vessel is consist of two junctions which are AC junction and DC junction. AC junction consists of all equipment on the fishing vessel that required $\mathrm{AC}$ voltage to run such as propulsion motor and purse seine motor. DC junction consists of all equipment on the fishing vessel that required DC voltage to run such as radio navigation, navigation lamp, fish finder, and emergency lamp.

Each junction and the battery panel should be installed a good wiring that has the capability to deliver the electricity and also safe during the operation. In calculating the right wiring for each installation, it needs to calculate the nominal current. Nominal current can be calculated using these formulas:

- For three phase AC current: 
Where, $\cos \theta=0,8$

$$
I_{\text {nominal }}=P /(380 \times \sqrt{3} \times \cos \omega \theta)
$$

- For DC current:

$$
\mathrm{I}_{\text {nominal }}=\mathrm{P} / \mathrm{V}
$$

After knowing the nominal current, the wiring can be selected by picking the value of nominal current as the minimum value of current the wiring should deliver.

Besides selecting the right wiring, it also needs to select the right busbar that can deliver the electricity safely. In order to select the right busbar, it needs to calculate the busbar current by using the formula below:

$$
\mathrm{I}_{\text {busbar }}=4 \times \mathrm{I}_{\text {nominal }}
$$

After knowing the busbar current, the busbar can be selected by picking the value of busbar current as the minimum value of current the busbar should deliver.

As for the complete wiring diagram and battery room layout can be seen in the attachment.

\section{CONCLUSION}

The optimum battery for Natuna Sea electric fishing vessels $10 \mathrm{GT}$ is $6000 \mathrm{Ah}$ with the range of distance about $14 \mathrm{NM}$, speed service about 7 knots, and fishing activities about 6,5 hours.

\section{ACKNOWLEDGEMENT}

The authors gratefully acknowledge the facility of software provided by Marine Manufacturing and Design (MMD) Laboratory, Marine Engineering Department, ITS Surabaya

\section{REFERENCES}

[1] Pusat Data, Statistik, dan Infromasi. "Potensi Kelautan dan Perikanan Kabupaten Natuna.” Jakarta: Kementrian Kelautan dan Perikanan., 2016.

[2] Pusat Pendidikan Kelautan dan Perikanan. "Penangkapan Ikan dengan Purse Seine". Jakarta: Kementrian Kelautan dan Perikanan, 2012

[3] Badan Pusat Statistik. "Statistik Ketenagakerjaan Kabupaten Natuna 2017", 2017.

[4] Kementrian Kelautan dan Perikanan RI. "Laporan Tahunan Kementrian Kelautan dan Perikanan Tahun 2016". Jakarta: Kementrian Kelautan dan Perikanan, 2017.

[5] Food and Agriculture Organization (FAO). "Fisherman's Workbook. Oxford: Fishing News Books', 1990.

[6] Gurning, S. (n.d.). Aplikasi Pendanaan Kapal. Surabaya.

[7] T. T. T. Pham, O. Flaaten, dan T. K. A. Nguyen, "Remuneration Systems and Economic Performance: Theory and Vietnamese Small-scale Purse Seine Fisheries," Mar. Resour. Econ., vol. 28, no. 1, hlm. 19-41, Jan 2013.

[8] Rashid, M. H. Power Electronic Handbook". 2001.

[9] Crompton, T. R. "Battery Reference Book Third Edition. Oxford: Newnes", 2000.

[10]Cultu, M. "Batteries and Their Chemistry", 2009.

[11] In Y. Gogus, "Energy Storage Systems". Paris: Eolss Publishers. 2009.

[12] Shawyer, M., \& Pizzali, A. F. "The Use of Ice on Small Fishing Vessel". Rome: FAO., 2003.

[13] M. B. Ndaliman dan U. Y. Suleiman, "An Economic Model for Break-even Analysis," hlm. 6.

[14] D. Deepak Sharma dan S. N. Singh, "Electrical load profile analysis and peak load assessment using clustering technique," dalam 2014 IEEE PES General Meeting | Conference \& Exposition, National Harbor, MD, USA, 2014, hlm. 1-5.

[15] S. Xiong dan X. Li, "Empirical Analysis: The Parameter and Internal Rate Return (IRR) of Wind Power Factory in China," dalam 2010 International Forum on Information Technology and Applications, Kunming, China, 2010, hlm. 377-380. 